\title{
Labor Legislation of Russia in the Era of the COVID-19 Pandemic: New Challenges for the Labor Sector
}

\author{
Svetlana Yu. Golovina, Yuliya A. Kuchina, Alena V. Serova* \\ Department of labor law, Ural State Law University, 620137 Yekaterinburg, Russia \\ *Corresponding author. Email: a.v.serova@usla.ru
}

\begin{abstract}
The COVID-19 pandemic has become a real challenge for state policy in the field of socio-economic relations in most countries of the world, including Russia. It caused a crisis in both the economy and the labor market. In such conditions, it is necessary to adjust the socio-economic policy of Russia as quickly as possible. At the same time, one of the leading directions of changes should be recognized as the transformation of labor legislation in order to adapt to the conditions of emergency situations. On the one hand, it should continue to promote the protection of workers' labor rights, especially in terms of their life and health, employment and income. On the other hand, labor law should not ignore the interests of employers in order to ultimately preserve the employment of citizens. In a number of Russian regulations, there are references to the specifics of labor regulation in the event of an emergency. However, these norms are clearly not enough for such a force majeure as the COVID-19 pandemic, and the existing regulations cause a lot of problems in the law enforcement process. The measures that are now being taken by the Russian state to prevent the spread of the new COVID-19 infection and minimize its adverse consequences, partly help to solve the problems that have arisen. However, they are adopted on an emergency basis, since there is no corresponding legislative regulation of such issues. In addition, a number of theoretical questions arise. So, for example, new to the science of labor law are the issues of establishing remote work, non-working days, self-isolation and social distancing.
\end{abstract}

Keywords: labor relations, pandemic, remote work, non-working days, extraordinary circumstances

\section{INTRODUCTION}

The pandemic of coronavirus infection COVID-19, officially announced by WHO on March 11, 2020, has become not only an urgent medical problem, but also had a major impact on sales markets, supply (production of goods and services), demand (consumption and investment) and the world of work [1].

As the International Labor Organization (hereinafter referred to as the ILO) rightly points out, "the global viral pandemic ... can lead to socio-economic shocks that will have detrimental consequences for the livelihoods and well-being of millions of people" [2].

According to preliminary analyzes published by the ILO on March 18, 2020, a pandemic could lead to the fact that about 25 million people could become unemployed [3]. In this regard, the ILO calls on the participating countries, which include the Russian Federation (hereinafter referred to as Russia/RF), to take prompt, coordinated measures, including measures to strengthen social protection of the population, to promote employment, to introduce financial benefits for employers, especially those that are small and medium-sized businesses.

Russia, as a member country of the ILO, supports its instructions. However, at the same time, according to a study by hh.ru, conducted with respect to 83 Russian employers from May 26 to May 29, 2020, 45\% of the respondents announced the reduction of company employees; the wage fund with the onset of the current crisis has decreased in $56 \%$ of the surveyed companies (on average, the decrease occurred by $28 \%$ ) [4].

These studies, at least, indicate the need to adjust the state policy of Russia in the development of socio-economic relations in order to ensure the priority implementation of measures to protect the labor rights of workers during the crisis period, especially in terms of their life and health, employment and income.

However, one should not forget the fact that according to Art. 1 of the Labor Code of the Russian Federation of December 30, 2001 No. 197-FZ (hereinafter referred to as LC RF), the purpose of labor legislation is to protect not only the rights of workers, but also the interests of employers, therefore, undoubtedly, the changes should not lead to the employer's loss of the opportunity to ensure the preservation of their own competitiveness.

\section{MATERIALS AND METHODS}

The methodological basis of the research is based on universal, general scientific methods, as well as some 
special methods comparative-legal).

(system-structural, formal-legal,

\section{LABOR LAW STANDARDS FOR EMERGENCY CIRCUMSTANCES}

The presence of an effective set of measures aimed at the legal regulation of relations in the world of work in the event of an emergency is a necessary condition for the implementation of one of the main tasks of labor legislation, formulated in Art. 1 of the Labor Code of the Russian Federation: creation of the necessary legal conditions for achieving optimal coordination of the interests of the parties to labor relations, the interests of the state.

Most often, extraordinary circumstances are understood as "approximate lists of natural disasters, natural phenomena" [5]. It is in this sense that extraordinary circumstances are considered in Russian labor legislation. So, according to Art. 4 of the LC RF, emergency situations are recognized as cases of disaster or threat of disaster (fires, floods, hunger, earthquakes, epidemics or epizootics) and other cases that endanger the life or normal living conditions of the entire population or its part.

Despite the fact that officially at the federal level, the pandemic of a new coronavirus infection was not recognized as an emergency in the context of the Labor Code of the Russian Federation, the regulations of individual constituent entities of the Russian Federation contain an understanding of the pandemic as an emergency. So, in clause 20.1 of the Decree of the Mayor of Moscow dated March 5, 2020 No. 12-UM "On the introduction of a high alert regime", it is established that the spread of a new coronavirus infection is an emergency and unavoidable circumstance under the current conditions, which entailed the force majeure circumstance. A similar qualification of a pandemic of a new coronavirus infection is given in the regulations of the Republic of Mari El, the Trans-Baikal Territory, the Nizhny Novgorod Region, etc.

Accordingly, in extreme circumstances, the following restrictions may be applied:

- exclusion from the category of "forced labor" of work performed in emergency conditions (paragraph 4, part 4, article 4 of the LC RF);

- the possibility of concluding a fixed-term employment contract by agreement of the parties to carry out urgent work to prevent emergencies (paragraph 5, part 2, article 59 of the LC RF);

- the possibility of temporary transfer of an employee without his consent for a period of up to one month to work not stipulated by an employment contract with the same employer to prevent these cases or eliminate their consequences (part 2 of article 72.2 of the LC RF);

- the possibility of terminating an employment contract in the event of an emergency that prevents the continuation of labor relations, if this circumstance is recognized by a decision of the Government of the Russian Federation or a government body of the corresponding constituent entity of the Russian Federation (clause 7, part 1 of article 83 of the LC RF);

- the possibility of attracting an employee to overtime work (clause 3, part 3, article 99 of the LC RF) or to work on weekends and non-working holidays without his consent (clause 3, part 3, article 113 of the LC RF).

In our opinion, this set of restrictive measures does not allow effectively and taking into account the interests of both parties to the labor relationship to respond to the difficult situation in the world of work caused by the COVID-19 pandemic, primarily due to the fact that they are not designed for such a new phenomenon for Russian reality as a massive self-isolation of citizens.

It must be said that most of the above measures concern restricting the right to freedom of labor, legalizing, in fact, "lawfully forced" labor [6]. Undoubtedly, in an emergency situation, the employer's demand for additional employment of an employee is justified, which qualitatively or quantitatively increases the measure of labor (work outside the established duration of working hours, performance of work not provided for by an employment contract) in an emergency.

At the same time, it is seen as necessary in order to balance the interests of the parties to the labor contract and the state, to maintain the quality of working life of workers as a necessary goal of labor legislation [7], to preserve the necessary amount of guarantees for workers to minimize the negative consequences of restrictions on freedom of labor. For example, by allowing the employer to involve employees in work on weekends and non-working holidays without their consent, the legislator in Art. 113 of the LC RF did not establish a time limit for such employment. Accordingly, the situation is not excluded when an employee will be obliged to spend the whole day off at work (or even two days off in a row), and on a weekly basis.

Today, this problem, first of all, concerns medical workers, employees of social institutions, employees of the Federal Service for Supervision of Consumer Rights Protection and Human Welfare, whose workload has grown many times over, due to which these persons experience serious physical overload and psychological stress [8].

In our opinion, for such situations it is necessary to provide in Art. 113 of the LC RF by analogy with Art. 99 of the LC RF concerning overtime work, the restriction on additional employment is at least within 120 hours per year. Otherwise, with such serious workloads associated with a sharply increased labor intensity, the working capacity of workers engaged in urgent work in emergency conditions will decrease, which ultimately can lead to a decrease in the quality of the job function, occupational burnout, disability and occupational diseases. Fatigue provokes a loss of concentration, and this, in turn, can lead to grave consequences, because it is no coincidence that "the cause of many accidents, technical failures, emergency incidents at enterprises, man-made disasters, etc. often called the human factor" [9]. 
In addition, the norm of Part 3 of Art. 72.2 of the LC RF, according to which if extraordinary circumstances caused a downtime or the need to replace a temporarily absent employee, it is allowed to transfer the employee for a period of up to one month to a job not stipulated by the employment contract with the same employer. The problem is that there is no legislative limitation of situations in which the corresponding rule can be used. It is quite logical when employers have a corresponding right when it is necessary to eliminate negative consequences caused by emergency circumstances, but the use of this rule in other situations may constitute an abuse of the right by the employer.

Literal interpretation of Part 3 of Art. 72.2 of the LC RF allows us to conclude that during a pandemic, an employer can transfer an employee to another job for up to 1 month without their consent, for example, to replace an absent colleague for a completely planned reason (annual leave). M.S. Sagandykova aptly notes that "the provisions of Parts. 2 and 3 of Art. 72.2 of the LC RF untie the hands of employers in cases where the work is related to the wellbeing of the population" [10].

It is necessary, in our opinion, to strengthen the guarantee of the stability of labor relations, specifying that transfer without the consent of workers to replace an absent worker is possible only in extreme circumstances. This will fully comply with paragraphs. "D" clause 2 of Art. 2 of the ILO Convention No. 29 concerning Forced or Compulsory Labor (Geneva, June 28, 1930), which does not include any work or service required in emergency situations as forced labor.

Special measures established by modern labor legislation in the event of emergencies are designed, first of all, for a situation where an emergency has arisen in a limited area. This, in our opinion, is evidenced by the examples of those cases that are directly attributed by the LC RF to extraordinary circumstances (for example, fire, flood, earthquake, epizootic).

In addition, it is assumed that these circumstances are short-lived in time and suggest an early return to normal life. However, the COVID-19 pandemic, due to the nature of the virus, which has a high degree of contagiousness and, as a result, has affected the whole world, has become an exception to the general rule. Accordingly, since a return to normal life is unlikely in the near future, it is necessary to provide for a long-term response in an emergency such as the COVID-19 pandemic.

On the one hand, the effectiveness of the existing restrictions should be assessed in terms of the time frame of their application in the context of the Covid-19 pandemic in our country. For example, employers actively supported the proposal of the Ministry of Labor and Social Protection of the Russian Federation, expressed in the draft resolution of the Government of the Russian Federation "On the specifics of legal regulation of labor relations in 2020" [11].

The Ministry of Labor of Russia proposed to secure an increase in the period for transferring an employee without their consent to work not stipulated by an employment contract with the same employer up to three months in order to prevent or eliminate the consequences of an epidemic or any exceptional cases that endanger the life or normal living conditions of the entire population or part of it. This rule would be relevant for those employers whose activities are limited due to the pandemic. For example, the volume of air transportation during the epidemic fell by $85 \%$ within the country and by more than $90 \%$ abroad, as stated by the President of the Russian Federation V.V. Putin at a meeting on support to the aviation industry [12]. Accordingly, the transfer of pilots, flight attendants, technical personnel, whose services were not in demand, to another job, provided that all the requirements of Art. 72.2 of the LC RF would help the employer solve the personnel problem for a period longer than a month. Nevertheless, in the final document-Decree of the Government of the Russian Federation of June 19, 2020 No. 887 "On the specifics of legal regulation of labor relations and other relations directly related to them in 2020 "- they decided to refuse to increase the duration of the transfer, noting that "since the submission of the previous edition, a significant part of the restrictive measures have been removed and certain provisions of the draft resolution have lost their relevance" [13].

However, scientists do not exclude the danger of a periodic resumption of viral infection and predict that outbreaks of the disease will occur in the future. Therefore, in our opinion, it is necessary to develop new legal measures that would be aimed at overcoming the negative socioeconomic consequences of the pandemic in the world of work.

The solution to the problem is seen in the formation in Section XII of the LC RF of a new chapter with a special purpose, where it is possible to concentrate all special rules that will replace the general norms of labor law during periods of emergency, including epidemiological situations. Such a chapter may be called "Peculiarities of labor regulation in emergency situations" and establish a special legal regime for the duration of force majeure circumstances, for example, include the following rules:

- on the temporary transition to remote work;

- on temporary suspension from work (non-admission to work) for reasons of a sanitary and epidemiological nature with full or partial retention of wages or payment of social insurance benefits (as is now provided for employees over 65 years of age);

- on a temporary change in the terms of the employment contract, including transfers to another job, without the consent of the employee and with a short notice period;

- on the possibility of using electronic images of documents if the employee does not have an electronic signature during the period of work outside the employer's location;

- other special rules, the presence of which is dictated by the need to prevent or eliminate the dangerous consequences of emergencies that endanger the life, health or normal living conditions of the population.

As the practice of combating the spread of the Covid-19 coronavirus infection has shown, the existing legal means 
of responding to such situations in labor law are insufficient.

\section{ADDITIONAL MEASURES TAKEN BY THE RUSSIAN STATE TO PREVENT THE SPREAD OF COVID-19, AND THEIR IMPACT ON THE WORLD OF WORK}

The measures that are now being taken by the Russian state to prevent the spread of the COVID-19 coronavirus infection and minimize its adverse consequences, in part, help to solve the problems that have arisen in the world of work. In this regard, a whole complex of regulatory and law enforcement documents of the federal, regional, local and local levels has already been adopted. However, they are adopted on an emergency basis, therefore, developers do not always manage to fully take into account international labor standards and foreign experience in regulating labor relations in a pandemic [14], the fundamental provisions of the LC RF, requirements of legislative technology and other rules for the formation of regulatory legal acts.

The measures that directly or indirectly relate to the world of work include the following:

- Establishing, in order to ensure the sanitary and epidemiological well-being of the population on the territory of the Russian Federation, a non-working day regime with the preservation of wages for employees from March 30 to April 30 and from May 06 to 08, 2020 (Decrees of the President of the Russian Federation of March 25, 2020 No. 206 "On declaration of non-working days in the Russian Federation", dated April 2, 2020 No. 239 "On measures to ensure the sanitary and epidemiological well-being of the population on the territory of the Russian Federation in connection with the spread of a new coronavirus infection (COVID-19)", dated April 28, 2020 No. 294 "On the extension of measures to ensure the sanitary and epidemiological well-being of the population in the Russian Federation in connection with the spread of the new coronavirus infection (COVID19)");

- from May 12, 2020, the right to make decisions on the suspension (limitation, including by determining the specifics of the operating mode, the number of employees) of the activities of individual organizations located on the territory of a certain constituent entity of the Russian Federation, as well as individual entrepreneurs, has been delegated to the heads of the highest executive bodies of state power of the Russian Federation, which must adopt the relevant regulatory legal acts based on the sanitary and epidemiological situation and the peculiarities of the spread of COVID-19 in the constituent entity of the Russian Federation (Decree of the President of the Russian Federation of May 11, 2020 No. 316 "On determining the procedure for extending measures to ensure sanitary and epidemiological welfare of the population in the constituent entities of the Russian Federation in connection with the spread of a new coronavirus infection (COVID-
19)"). In this case, employees should also retain their wages;

- in order to take measures to implement the state guarantee of the constitutional right of citizens of the Russian Federation to protection from unemployment, simplified rules were approved for registering citizens as looking for suitable work and as unemployed (Resolution of the Government of the Russian Federation of April 8, 2020 No. 460 "On Approval of the Temporary Registration Rules for citizens as looking for a suitable job and as unemployed, as well as the implementation of social benefits to citizens recognized as unemployed in the prescribed manner"). Since "the system of protecting citizens from unemployment ... also includes such a mandatory element as material support for citizens looking for work or recognized as unemployed" [15], the amount of unemployment benefits was increased for the period from April to August 2020, and citizens dismissed and recognized as unemployed in accordance with the established procedure starting from March 1, 2020 and having children under the age of 18 , the amount of unemployment benefits in April-June 2020 was increased in proportion to the number of such children at the rate of 3000 rubles for each child to one of the parents, foster parent, the adoptive parent, as well as the guardian, trustee (Resolution of the Government of the Russian Federation of March 27, 2020 No. 346 "On the size of the minimum and maximum amounts of unemployment benefits for 2020");

- in order to take measures to implement the rights of citizens to health protection, it is envisaged to issue temporary disability sheets to employees aged 65 and over who adhere to the self-isolation regime during the quarantine period (Resolution of the Government of the Russian Federation of April 1, 2020 No. 402 "On Approval of the Temporary Rules registration of certificates of incapacity for work, appointment and payment of benefits for temporary incapacity for work in case of quarantine to insured persons aged 65 and over");

- significant changes affected the labor protection institute. Firstly, recommendations were developed on organizing the work schedule of workers and observing preventive measures that prevent the spread of COVID-19 (Resolution of the Chief State Sanitary Doctor of the Russian Federation of March 13, 2020 No. 6 "On additional measures to reduce the risks of the spread of COVID-2019"). The Federal Service for Supervision of Consumer Rights Protection and Human Welfare recommended that employers take a number of organizational measures to prevent the spread of coronavirus infection, including the following measures: temporary suspension from work or transfer to remote work of persons from risk groups, which include persons older 65 years old, as well as those with chronic diseases, reduced immunity, pregnant women, with the provision of a self-isolation regime during the period of the rise and a high incidence of a new coronavirus infection (Letter of the Federal Service for Supervision of Consumer Rights Protection and Human Welfare dated April 7, 2020 No. 
02/6338-2020-15 "On recommendations for the prevention of coronavirus infection (COVID-19) among workers"). In the current situation, it is surprising that the competent authorities issued their documents in the form of recommendations, and not binding orders. Accordingly, they did not create legal obligations for employers. Secondly, the duration of measures aimed at occupational safety was extended. For example, the terms of training in labor protection or testing the knowledge of labor protection requirements of employees of organizations, the validity of the results of a special assessment of working conditions, which expire in the period from April to September 2020, are extended until October 1, 2020 (Resolution of the Government of the Russian Federation of April 3, 2020 No. 440 "On the extension of permits and other peculiarities in relation to licensing activities in 2020"), periodic medical examinations may be postponed, but for no more than 6 months (Order of the Ministry of Health of the Russian Federation of May 18, 2020 No. $455 n$ "On amending the Procedure for conducting mandatory preliminary (upon admission to work) and periodic medical examinations (examinations) of workers engaged in heavy work and in work with harmful and (or) hazardous working conditions, approved by order of the Ministry of Health and Social Development of the Russian Federation dated April 12, 2011 No. 302n");

- a measure of economic support for employers was the issuance of interest-free loans to pay wages to employees in the presence of several conditions: if they work in an industry that is included in the list of those most affected by the coronavirus; do not go through bankruptcy proceedings and continue to work; the number of employees of the borrower, if it does not belong to a small or micro-enterprise, in the reporting month is at least $90 \%$ of the number of employees in the previous month (Decree of the Government of the Russian Federation of April 2, 2020 No. 422 "On Approval of the Rules for Granting Subsidies from the Federal Budget to Russian Credit organizations to reimburse them for lost income on loans issued in 2020 to legal entities and individual entrepreneurs for urgent needs to support and maintain employment");

- Another novelty concerning the legal regulation of labor is associated with some redistribution of the rulemaking powers of the subjects of legislative and executive power. In 2020, the right to establish the specifics of legal regulation of relations in the labor sphere was granted to the Government of the Russian Federation (Article 17 of the Federal Law of April 1, 2020 No. 98-FZ (as amended on June 08, 2020) "On Amendments to Certain Legislative Acts of the Russian Federation on issues of prevention and elimination of emergency situations"). The result of the implementation of this right was the Resolution of the Government of the Russian Federation of June 19, 2020 No. 887 "On the specifics of legal regulation of labor relations and other directly related relations in 2020". From the initial draft, which contained proposals aimed at expanding the ability of employers to make operational personnel decisions, and, accordingly, reducing workers' guarantees, in the final version, only the rule remained on the postponement of the deadline for notifying employees about the need to choose between a paper or electronic work record book by 31 October 2020, as well as the peculiarities of exercising the rights of persons working in organizations located in the Far North and equivalent areas to reimburse the cost of travel and baggage transportation within the territory of the Russian Federation to the place of vacation and back in another calendar year;

- the main trend of the coronavirus period was the rapid transition to digital labor relations, as evidenced, first of all, by a sharp increase in the number of people working remotely using information and communication technologies. For example, practically the entire field of education-from schools to universities-switched to online education during the period of self-isolation. According to the Minister of Labor and Social Protection of the Russian Federation A. Kotyakov, during the peak periods of non-working days, according to operational monitoring on the portal "Work in Russia", almost $11 \%$ of employed citizens worked remotely. This is almost 6 million people. Today, about $9.5 \%$ of employed citizens continue to work remotely-over 5 million people. It is predicted that up to $5 \%$ of workers will remain working remotely even after the lifting of restrictive measures related to the pandemic [16]. This transition is not accidental: "the versatility of digital technologies has subordinated the whole world to its logic" [17].

The accelerated digitalization of relations in the world of work is evidenced by the new (contactless) procedure for contacting employment centers in order to find a suitable job: during the period of the high alert regime on the territory of the constituent entities of the Russian Federation, citizens submit documents in a remote form. It became possible to issue certificates of incapacity for work remotely without an in-person examination of a patient who has indications for quarantine. The Ministry of Labor of Russia, finally, offered employers the exchange of electronic images of documents, followed by their registration in the prescribed manner.

It must be said that the problem of expanding the field of application of electronic technologies in the world of labor has been discussed for several years in the legal literature, and experts rightly raise questions about the possibility of a wider use of electronic methods for collecting and processing information related to labor relations at all their stages, about the legalization of electronic office work in personnel affairs [18], on the consolidation of the employer's right to acquaint employees with local regulations, documents and decisions made in electronic form [19], on the introduction of digital technologies in relations for the management and organization of labor [20], etc.

In a broad context, the problem of key challenges for labor law that have arisen in connection with the development of information technologies is discussed: a change in the structure of employment (the transition of labor activity from the sphere of production to the sphere of services, the withering away of old and the emergence of new 
professions) and the transformation of labor relations in connection with the emergence of new forms of employment, leading to the erosion of the most important signs of labor relations, including the subordination of the employee to the employer and control over the implementation of labor as a process [21-23]. All this once again confirms the urgent need to modernize labor legislation in the direction of adaptation to the digital economy.

\section{PROBLEMS OF APPLICATION OF THE NEW RULES DURING THE PANDEMIC OF CORONAVIRUS INFECTION}

As practice has shown, urgently adopted regulations and the subsequent explanations and recommendations of the Ministry of Labor of Russia and the Federal Service for Supervision of Consumer Rights Protection and Human Welfare caused serious difficulties in their implementation. There are many reasons for scientific reflection. Here are some of them.

In recent months, the conceptual apparatus of labor law has been replenished with new categories previously unknown to labor legislation: "remote work", "nonworking days", "preservation of wages", "self-isolation", "social distancing", "electronic image of a document". However, their regulatory elaboration is either absent altogether, or rather schematic. This raises a huge number of questions related to how the employer can practically implement the measures proposed by the state to prevent the spread of coronavirus infection.

The first problem faced by employers in connection with the adoption of the Decrees of the President of the Russian Federation on non-working days is the absence in the Labor Code of the Russian Federation of the relevant terms and legal structures that are used by the Decrees of the President of the Russian Federation. First of all, this concerns the concept of "non-working days". The Labor Code of the Russian Federation understands rest time as non-working days, namely, weekends and non-working holidays, and, as a rule, they are used in the code together, since practically the same rules are established for them (prohibition of work on non-working weekends and holidays, increased pay for work on these days, etc.).

As for non-working days according to the decrees of the President of the Russian Federation, then, despite the fact that workers are released from work, they cannot be attributed to the time of rest, because Art. 107 of the LC RF contains a closed list of types of rest time. In addition, the very definition of the concept of rest time (Article 106 of the LC RF) contains an important characteristic: an employee can use it at their own discretion, and with non-working days the situation is somewhat different, since their provision is of a targeted nature (ensuring social distancing).

In this connection employees must comply with the requirement of isolation at home and cannot use their free time at their discretion, for example, go to the theater or to sports events. Non-working days according to the Decree of the President of the Russian Federation are not intended for rest, but for minimizing contacts between people. The Ministry of Labor of Russia in its letter dated March 26 , 2020 No. 14-4/10/P-2696 confirms that non-working days do not belong to weekends or non-working holidays, therefore, employees of organizations that continue to work during the coronavirus pandemic are paid in regular, not oversized.

The second problem concerns the preservation of wages for released workers. The fact is that the Labor Code of the Russian Federation uses a different term to pay for days off work- "average wages (average earnings)" (Article 139). Obviously, "preservation of wages" and "preservation of average earnings" cannot be considered identical concepts, and therefore the method of calculating wages for the period of declared non-working days is unclear.

None of the three decrees of the President of the Russian Federation on non-working days establish a mechanism for implementing the requirement to preserve wages. In fact, this payment is not a wage, the main characteristic of which (and at the same time a generic feature) is remuneration for work. It seems that such a guarantee payment should be considered compensation for lost earnings, and, in our opinion, the situation with nonworking days is inherently closer to downtime due to circumstances beyond the control of the employer and the employee, respectively, it would be appropriate to use Art. 157 of the LC RF "Payment for forced downtime".

However, since in the Decrees of the President of the Russian Federation the concept of "wages" is used, then based on its definition given in Art. 129 of the LC RF, employers are obliged to pay employees for the period of non-working days not only the amount of the base part of wages (salary, tariff rate), but also compensation and incentive payments. This conclusion is confirmed by the Ministry of Labor of Russia in a Letter dated March 26, 2020 No. 14-4/10/P-2696: "The amount of payment should correspond to that which the employee would receive if they worked these days in full (worked the standard of working time with hourly pay, fulfilled the standard of work at piecework payment)". And here no longer legal, but exclusively economic problems arise.

Employers whose activities have been suspended due to the spread of the COVID-19 coronavirus infection, experiencing financial difficulties due to lack of income, even if they want to keep their employees' income level, are not actually able to do so in full. Back in March 2020, when the first non-working days were announced, employers, realizing that restrictive measures would not be short-term, began to minimize their costs by reducing payments to employees (taking vacations without pay, setting part-time work, forcing employees to writing letters of resignation, declaring downtime, etc.).

It is naive to expect employers to find money to maintain full wages of workers without financial support from the state. In our opinion, in such emergencies, it is the state that should bear the financial costs for the implementation of its own guarantee of maintaining wages. Otherwise, the 
guarantee will remain only on paper, and employers, at best, will draw up a simple one for reasons beyond the control of the parties to the labor relationship, and retain $2 / 3$ of the salary, the tariff rate for the employees, as required by Art. 157 of the Labor Code of the Russian Federation, and at worst, to fire workers en masse.

Another new term that entered the conceptual apparatus of labor law "with a light hand" of the Ministry of Labor of Russia is "remote work". Until now, the category of "remote work" has been only a subject of scientific discussions [24], it has not been legislatively consolidated and used. Accordingly, employers who follow the instructions of the Ministry of Labor of Russia on the use of flexible working modes have natural questions: how to fulfill the recommendations of state authorities to transfer employees to remote work when such an opportunity is not provided for in the Labor Code of the Russian Federation; what is the procedure for transferring to remote work, is the consent of the employee necessary and how to draw it up in self-isolation; how to create conditions for remote work for the employee as quickly as possible, what to set the mode of work and rest, how to provide equipment, software and hardware, information security means in the conditions of coronavirus; whether it is necessary to compensate the employee for communication costs, Internet, etc.

Some of the questions received their answers in the explanations of the Ministry of Labor of Russia. For example, the problem of formalizing changes in the terms of an employment contract (and the transition to work remotely is, at least, a change in the conditions of the place of work, and possibly also the mode of work and rest, and the amount of remuneration), the Ministry of Labor of Russia proposes to solve it by exchanging electronic images of documents with their subsequent registration in the prescribed manner (Information of the Ministry of Labor of Russia dated March 27, 2020 "Addendum to the Recommendations for employees and employers in connection with the Decree of the President of the Russian Federation dated March 25, 2020 No. 206 "On the announcement of non-working days in the Russian Federation").

However, we emphasize once again that letters from the Ministry of Labor of Russia, including those with legally significant information, are not normative acts, and therefore cannot serve as sources of labor law for employers. And by no means all of the questions that arise were answered in the clarifying documents of the regulator.

It is no coincidence that the Minister of Labor and Social Protection of the Russian Federation A. Kotyakov noted that "over 3 months, Rostrud received over 330 thousand requests from employees and employers, $90 \%$ of which were of a consulting nature. Moreover, most of the issues were related to the organization of remote work" [16]. It would seem that the Labor Code of the Russian Federation has Chapter 49.1, dedicated to the peculiarities of labor regulation of teleworkers, as well as Chapter 49, which applies to homeworkers.
However, today in judicial practice, the opinion is widespread that the provisions of Chapter 49.1 of the LC RF can only be applied to employees who have entered into an employment contract on teleworking (Decision of the Stupinsky City Court of the Moscow Region of July 30, 2018 in case No. $2-1331 / 2018$, decision of the Kola District Court of the Murmansk Region dated June 09, 2018 in case No. 2-730/2018). The work of a homeworker by its nature presupposes the production of "certain products, which cannot be said about office workers" [25] Accordingly, amendments should be made to the Labor Code of the Russian Federation aimed at the possibility of combining work performance outside the employer's location and at a stationary workplace, which has been repeatedly discussed by scientists-specialists in the field of labor law [26, 27].

We can say that the pandemic served as a catalyst for the legislative process. Currently, a draft federal law No. 973264-7 "On amendments to the Labor Code of the Russian Federation regarding the regulation of remote and remote work" 28] has been submitted to the State Duma of the Russian Federation, which should be considered in the summer months.

The bill introduces new concepts into legal terminology"combined remote work" and "temporary remote work. Combined remote work is an operation mode that includes work at a stationary workplace and remote work. The grounds for establishing a regime of temporary remote work may be an agreement of the parties, an industrial necessity, a natural or man-made disaster, an industrial accident, a fire, a flood, an earthquake, an epidemic, an epizootic and any exceptional cases that endanger life or normal living conditions of the entire population or part of it.

The bill provides for a simplified procedure for the introduction of a temporary remote work regime (without changing the terms of an employment contract), which should include the issuance of a local normative act with the establishment of lists of employees who are transferred with their consent to temporary remote work, as well as the procedure for organizing a temporary remote work. The adoption of the bill will eliminate the conflicts and gaps that exist today in labor legislation regarding remote work.

In conclusion, we note that all that has been said is only a part of the problems faced by labor law subjects in emergency conditions caused by the implementation of measures to prevent the spread of COVID-19 coronavirus infection.

\section{CONCLUSION}

The pandemic of coronavirus infection COVID-19, which posed a real threat to the life and health of the population of the Russian Federation, required the state to make urgent and not always popular decisions that significantly affected all spheres of society, including the world of work. As it turned out, labor legislation does not have sufficient tools for solving short-term problems associated 
with the need for social distancing of people, and also does not offer fundamental solutions for new forms of employment.

Obviously, the problem of a radical modernization of labor legislation has become aggravated in the direction of increasing the mobility of labor resources in all its manifestations, the development of remote employment, and the active introduction of electronic document management into employers' practice.

The coronavirus infection COVID-19 not only exposed the problems of labor legislation, but also generated a public request to find new legal mechanisms to help overcome the negative consequences caused by emergencies. All this requires scientific understanding and justification.

Today, the tasks of the science of labor law are:

- timely accumulation, systematization and analysis of regulations and law enforcement acts that already exist and are being adopted in order to prevent emergencies, including the spread of the COVID-19 coronavirus infection;

- a thorough scientific analysis of new categories and their comparison with related categories so that they can be built into the system of the conceptual apparatus of labor law;

- identification and adaptation of existing structures of labor law that can help in the fight against emergencies, including with the coronavirus infection COVID-19;

- assessing the impact of new labor law measures applied in connection with COVID-19 on socio-economic relations and forecasting long-term consequences;

- formation of scientifically grounded recommendations for amending the current labor legislation in order to adapt it to emergency situations.

Taken together, the above measures will allow, firstly, to take into account the experience of combating the coronavirus infection COVID-19 for possible future similar situations, and secondly, to speed up the ongoing transformations in the economy and labor (for example, in terms of digitalization of relations in the world of work) and thirdly, to stabilize the crisis socio-economic situation.

\section{REFERENCES}

[1] International Labor Organization, In the face of a pandemic: Ensuring safety and health at work, ILO, Geneva, 2020, p. $8 . \quad$ Retrieved from: https://www.ilo.org/wcmsp5/groups/public/--ed_protect/---protrav/--

safework/documents/publication/wcms_742463.pdf.

[2] International Labor Organization, COVID-19 and the world of work, Retrieved from: https://www.ilo.org/moscow/news/WCMS_738764/lan g--en/index.htm.

[3] International Labor Organization, COVID-19 and the world of work: Impact and policy responses, ILO
Monitor 1st Edition, 18 March 2020, p. 3. Retrieved from: https://www.ilo.org/wcmsp5/groups/public/--dgreports/---

dcomm/documents/briefingnote/wcms_738753.pdf.

[4] Cuts or increases in staff and salaries? Current plans of employers, Retrieved from: https://hh.ru/article/26889? customDomain=1.

[5] A.I. Frolov, On extraordinary circumstances in civil law, Bulletin of Tomsk State University, Law 3(9) (2013) 101.

[6] V.V. Zhernakov, Freedom of Labor and the Prohibition of Forced Labor in Modern Labor Law, Bulletin of Perm University, Legal Science 3(21) (2013) 93

[7] S.Yu. Golovina, Yu.A. Kuchina, A.V. Serova, Increasing the Quality of Working Life: Modern Labor Legislation's Strategic Task, Advances in Social Science, Education and Humanities Research 333 (2019) 719.

[8] Yu. Onishchenko, Working weeks without days off are now at doctors who are fighting a dangerous virus, March 29, 2020. Retrieved from: https://www.1tv.ru/news/2020-03-29/ 382825rabochie_nedeli_bez_vyhodnyh_seychas_u_vrachey_k otorye_vedut_borbu_s_opasnym_virusom.

[9] A.A. Tatarinov, Impact of labor law on improving the efficiency of the human factor, Labor law in Russia and abroad 2 (2017) 55.

[10]M.S. Sagandykov, Implementation of the constitutional principle of freedom of labor during temporary transfers to another job, Bulletin of Perm University, Legal Sciences 3(21) (2013) 170.

[11]Letter of the Ministry of Labor of Russia dated May 28, 2020 No. 14-5/10/P-5009 "On the draft resolution of the Government of the Russian Federation "On the specifics of legal regulation of labor relations in 2020." Retrieved from: https://www.garant.ru/products/ipo/prime/doc/7413701 $0 /$.

[12]P. Eskov, The government has allocated 23.4 billion rubles to support airlines, Finansovaya Gazeta, May 14, 2020. Retrieved from: https://fingazeta.ru/ekonomika/rossiyskaya_ekonomika/ 462811?utm_source=facebook\&utm_medium=social \& utm_term=pravitelstvo-podderzhit-aviakompanii-na23\&utm_content=7920602. 
[13] The Ministry of Labor has finalized the draft resolution on the regulation of labor relations. Retrieved from: https://astv.ru/news/mir/2020-06-10-mintruddorabotal-proekt-postanovleniya-o-regulirovanitrudovyh-otnoshenij.

[14] Special Issue: Covid-19 and Labor Law. A Global Review, Italian Labor Law e-Journal 13(1S) (2020) Retrieved from: https://illej.unibo.it/issue/view/868.

[15] L.A. Chikanova, L.V. Seryogina, Legal protection of citizens from unemployment in the context of information technological innovations in the sphere of labor and employment, Law, Journal of the Higher School of Economics 3 (2018) 160.

[16] Ministry of Labor of Russia, During non-working days, up to 6 million employed Russians worked remotely, June 25, 2020. Retrieved from: https://mintrud.gov.ru/employment/61.

[17]E.V. Talapina, Digital Transformation in France: Legal Novels, Law, Journal of the Higher School of Economics 4 (2019) 165.

[18] I.A. Kostyan, A.M. Kurennoy, G.V. Khnykin, Labor Law and the Digital Economy: Are They Combined? Labor Law in Russia and Abroad 4 (2017) 10-12.

[19] A.A. Tumanov, Informing workers using electronic resources of the employer, Labor law in Russia and abroad 2 (2018) 18-20.

[20]L.V. Zaitseva, Legal aspects of the use of local electronic document management systems to regulate labor relations, Labor law in Russia and abroad 3 (2018) 34-37.

[21] N.L. Lyutov, Adaptation of labor law to the development of digital technologies: challenges and prospects, Actual problems of Russian law 6(103) (2019) 98-107.
[22] K.L. Tomashevsky, Digitalization and its impact on the labor market and labor relations (theoretical and comparative legal aspects), Bulletin of the St. Petersburg State University, Pravo, 11(2) (2020) 406.

[23] N.V. Chernykh, Influence of atypical forms of employment on theoretical ideas about labor relations (using the example of norms on distance work), Actual problems of Russian law 8(105) (2019) 108-117.

[24]E. Gerasimova, T. Korshunova, D. Chernyaeva, New Russian Legislation on Employment of Teleworkers: Comparative Assessment and Implications for Future Development, Law, Journal of the Higher School of Economics 2 (2017) 117.

[25] N.V. Chernykh, Labor legislation of Russia vs coronavirus: who will win? Actual problems of Russian law 15(5(114)) (2020) 155.

[26] T.Yu. Korshunova, A teleworking agreement as a way of formalizing atypical labor relations, Journal of Russian Law 2 (2020). Retrieved from: http://www.consultant.ru/cons/cgi/online.cgi?req=doc $\&$ ts $=1314119455018406863346305458 \&$ cacheid $=C 2 B 02$ 09BB7C7C71B312B1B9D2A683492\&mode=splus \&ba $\mathrm{se}=\mathrm{Chd} 5492 \&$ mode $=$ splus $\&$ base $=\mathrm{C} 126$

[27] N.L. Lyutov, Remote work: the experience of the European Union and the problems of legal regulation in Russia, Lex Russica 10 (2018) 30-39.

[28] Official site of the State Duma of the Russian Federation. Retrieved from: https://sozd.duma.gov.ru/bill/973264-7. 